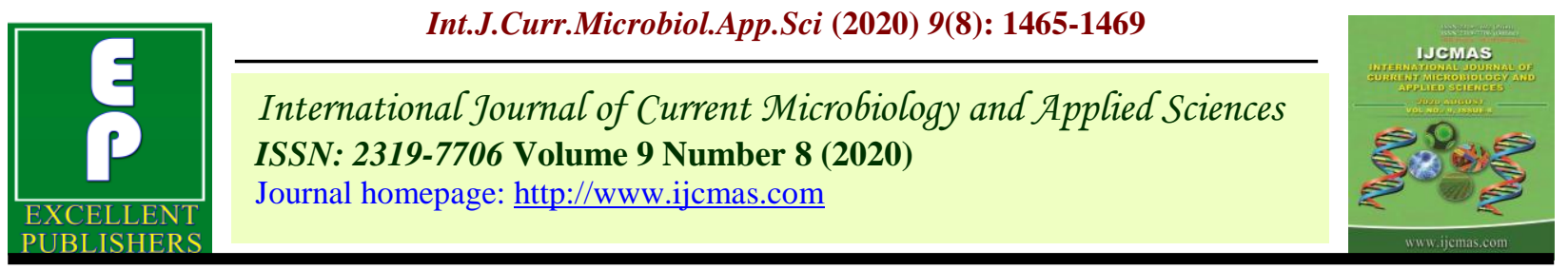

Original Research Article

https://doi.org/10.20546/ijcmas.2020.908.168

\title{
Evaluation Elite Grain Amaranth Genotypes for Major Insect-Pest Resistance
}

\author{
Anil $^{1 *}$, Prabhu Ganiger ${ }^{2}$, Srinivas Reddy $^{2}$ and Niranjanamurthy ${ }^{3}$ \\ ${ }^{1}$ Department of Entomology, ICAR- Indian Agricultural Research Institute (IARI), \\ New Delhi, India \\ ${ }^{2}$ University of Agriculture sciences, ${ }^{3}$ AICRP on Potential crops, GKVK, Bangalore, India \\ *Corresponding author
}

\begin{abstract}
A B S T R A C T
Keywords

Insect pests,

Genotypes,

Resistance and

Grain amaranth

Article Info

Accepted:

15 July 2020

Available Online:

10 August 2020

Investigation on evaluation grain amaranth genotypes against incidence of insect pests was undertaken at MRS, Hebbal, Bengaluru. During study period, among 32 genotypes screened against leaf webber at seedling stage, 25 genotypes were tolerant and 7 genotypes were highly tolerant. At vegetative stage 16, 10 and 6genotypes were highly tolerant, tolerant and moderately tolerant, respectively. At grain filling stage 14, 15 and 3 genotypes were moderately tolerant, susceptible and highly susceptible, respectively. The genotypes KBGA-5, RHGA-13-1, RHGA13-2, RMA-7, MGA-15, KBGA-4, BGA-38, BGA-43, SKGPA-75, RJAS-08-17, MGA-12, KBGA-7, IC-032193 and IC-035713 were tolerant at seedling, vegetative and grain filling stage ranging from 0 to 50 per cent leaf damage.
\end{abstract}

\section{Introduction}

One of the greatest limiting factors in increasing the productivity of leaf amaranth is the damage caused by wide range of insect pests in general, whereas defoliators can cause economic loss (Akinolosotu, 1977). Aderolu et al., (2013) reported 60 insect species associated with amaranthus crop. Hymenia recurvalis caused 8.8 per cent infestation, however, H.recurvalis and Psarabasalis were also common. Agarwal (1985) reported Hypolixus sp., is a major pest in cultivated amaranth. Leaf miner, Liriomyza sp. (Sorensen, 1995), aphid, Myzuspersicae are major pest of amaranthus causing leaves to curl and become unattractive for marketing (Picker et al., 2004; Okunlola et al., 2008). Richard (1989) reported that the leaf worms or cutworms Spodoptera sp., attack young seedlings. Amaranth leaf webber or webworm larvae fold or web amaranth leaves using their silken webs and feed within the leaves. Hymenia recurvalis, Psarabasalis, Herpetograma bipunctalis are major pests of grain amaranth (Batra and Bhattacherjee, 1960; Bhattacherjee et al., 1964 Clarke-Harris et al., 2003; James et al., 2010 and Grovida, 2015). Information on grain amaranth genotypes evaluated for insect pests found to 
be very scanty. Based on this information efforts were made to study the grain amaranth genotypes were screened against insect pests.

\section{Materials and Methods}

Screening of genotypes against major insect pests of grain amaranth under field conditions

Field experiment was laid out with a plot size of $3.27 \mathrm{~m} \mathrm{x} 2.27 \mathrm{~m}$. Amaranth belonging to 32 genotypes were screened against leaf webber with three replications. Five amaranth plants in each genotype were tagged randomly to record number of leaf webber and per cent damage caused by leaf webber at seedling stage, vegetative stage and grain filling stage of the crop.

The genotypes were classified as highly tolerant, tolerant, moderately tolerant, susceptible and highly susceptible based on the percent leaf damage done by leaf webber (Table 1 and Plate 2).

\section{Results and Discussion}

A total of 32 genotypes were screened against leaf webber under field conditions during 2016 (Table 2). Number of leaves damaged by the leaf webber at seedling, vegetative and grain filling stage of grain amaranth was recorded.
Leaf webber damage at seedling stage of grain amaranth

KBGA-8, GA-2, RHGA-13-2, RHGA-13-1, Suvarna, IC-032193, VL-44, KBGA-5, SKGPA-91, IC-035711, RMA-59, Annapurna, KBGA-10, KBGA-11, RMA-7, KBGA-7, MGA-12, RJAS-08-17, SKGPA75, BGA-38, BGA-43, KBGA-1, KBGA-4, MGA-15, IC-035713 were found to be highly tolerant with leaf damage was $0-5$ per cent. Leaf damage was 6-25 per cent in KBGA-9, BGA-7-1, BGA-29, SKKGPA-86, RGA-11, BGA-2 and SKGPA-74 with 6-25 per cent leaf damage (Table 2).

\section{Leaf webber damage at Vegetative stage of grain amaranth}

Among the amaranth genotypes, KBGA-5, RHGA-13-1, RHGA-13-2, RMA-7, MGA-15, KBGA-4， BGA-38， BGA-43， SKGPA-75, RJAS-08-17, MGA-12, KBGA-7, IC-032193 and IC-035713, leaf webber damage was 2650 per cent, which was significantly lesser than in other genotypes. This was followed by KBGA-8, BGA-7-1, BGA-29, SKKGPA-86, RGA-11, SKGPA-91, RMA-59, GA-2, Suvarna SKGPA-74 KBGA-1, GA-2, RMA-7 KBGA-11 and Annapurna with 51-75\% leaf damage. IC-035711, KBC-8, BGA-2 andKBGA-1076 recorded 100\% damage by leaf webber (Table 1).

Table.1 Scoring of grain amaranth genotypes based on leaf damage caused by leaf webber

\begin{tabular}{|c|c|c|}
\hline Scoring & $\begin{array}{c}\text { Per cent leaf } \\
\text { damage }\end{array}$ & Classification of genotypes \\
\hline $\mathbf{0}$ & $0-5$ & Highly tolerant \\
\hline $\mathbf{1}$ & $6-25$ & Tolerant \\
\hline $\mathbf{2}$ & $26-50$ & Moderately tolerant \\
\hline $\mathbf{3}$ & $51-75$ & Susceptible \\
\hline $\mathbf{4}$ & $76-100$ & Highly Susceptible \\
\hline
\end{tabular}

(Priya, 1998) 
Table.2 Screening of amaranth genotypes against leaf webber (Hymenia recurvalis) at different stages of crop growth

\begin{tabular}{|c|c|c|}
\hline Stages of genotypes & \multirow{2}{*}{$\begin{array}{l}\text { Leaf damage } \\
(\%)\end{array}$} & \multirow[t]{2}{*}{ Reaction } \\
\hline Seedling stage & & \\
\hline \multirow{2}{*}{$\begin{array}{l}\text { KBGA-8, GA-2, RHGA-13-2, RHGA-13-1, Suvarna, IC-032193, VL-44, KBGA-5, SKGPA-91, } \\
\text { IC-035711, RMA-59, Annapurna, KBGA-10, KBGA-11, RMA-7, KBGA-7, MGA-12, RJAS-08- } \\
\text { 17, SKGPA-75, BGA-38, BGA-43, KBGA-1, KBGA-4, MGA-15 and IC-035713. }\end{array}$} & $0-5$ & HT \\
\hline & $6-25$ & $\mathrm{~T}$ \\
\hline Vegetative stage & $0-5$ & HT \\
\hline $\begin{array}{l}\text { RHGA-13-1, GA-2, VL-44, RMA-7, KBGA-10, SKGPA-75, SKGPA-91, KBGA-5, KBGA-1, } \\
\text { KBGA-11, MGA-15, RHGA-13-2, KBGA-8, MGA-12, KBGA-7and IC-035713. }\end{array}$ & $6-25$ & $\mathrm{~T}$ \\
\hline $\begin{array}{l}\text { SKGPA-74, Suvarna, IC-032193, IC-035711, RMA-59, Annapurna, RJAS-08-17, BGA-43, } \\
\text { BGA-38, and KBGA-4. } \\
\text { BGA-2, RGA-11, SKKGPA-86, BGA-29, BGA-7-1 and KBGA-9. }\end{array}$ & $26-50$ & MT \\
\hline Grain filling stage & \multirow[t]{2}{*}{$26-50$} & \multirow[t]{2}{*}{ MT } \\
\hline \multirow{3}{*}{$\begin{array}{l}\text { KBGA-5, RHGA-13-1, RHGA-13-2, RMA-7, MGA-15, KBGA-4, BGA-38, BGA-43, SKGPA-75, } \\
\text { RJAS-08-17, MGA-12, KBGA-7, IC-032193, and IC-035713. } \\
\text { KBGA-8, KBGA-9, BGA-7-1, BGA-29, SKKGPA-86, RGA-11, SKGPA-91, RMA-59, GA-2, } \\
\text { Suvarna, SKGPA-74, KBGA-1, KBGA-11, Annapurna and VL-44. }\end{array}$} & & \\
\hline & $51-75$ & $\mathrm{~S}$ \\
\hline & & HS \\
\hline $\begin{array}{l}\text { HT : Highly tolerant; T : Tolerant; MT : Moderately tolerant; } \\
\text { S: Susceptible; } \quad \text { HS : Highly Susceptible }\end{array}$ & & \\
\hline
\end{tabular}


Table.3 Reaction of amaranth genotypes against leaf webber, Hymenia recurvalis

\begin{tabular}{|c|l|c|c|c|}
\hline SL.NO. & Genotypes & Leaf damage (\%) & Scoring & Reaction \\
\hline $\mathbf{1}$ & KBGA-8 & 49.40 & 2 & MT \\
\hline $\mathbf{2}$ & RHGA-13-1 & 41.50 & 2 & MT \\
\hline $\mathbf{3}$ & RHGA-13-2 & 41.65 & 2 & MT \\
\hline $\mathbf{4}$ & RMA-7 & 48.40 & 2 & MT \\
\hline $\mathbf{5}$ & MGA-15 & 44.20 & 2 & MT \\
\hline $\mathbf{6}$ & KBGA-4 & 46.62 & 2 & MT \\
\hline $\mathbf{7}$ & BGA-38 & 46.70 & 2 & MT \\
\hline $\mathbf{8}$ & BGA-43 & 47.13 & 2 & MT \\
\hline $\mathbf{9}$ & SKGPA-75 & 47.21 & 2 & MT \\
\hline $\mathbf{1 0}$ & RJAS-08-17 & 47.34 & 2 & MT \\
\hline $\mathbf{1 1}$ & MGA-12 & 47.41 & 2 & MT \\
\hline $\mathbf{1 2}$ & KBGA-7 & 47.65 & 2 & MT \\
\hline $\mathbf{1 3}$ & IC-032193 & 47.79 & 2 & MT \\
\hline $\mathbf{1 4}$ & IC-035713 & 47.84 & 2 & MT \\
\hline
\end{tabular}

MT: Moderately tolerant

\section{Leaf webber damage at grain filling stage}

Among the amaranth genotypes, KBGA-5, RHGA-13-1, RHGA-13-2, RMA-7, MGA-15, KBGA-4, BGA-38, BGA-43, SKGPA-75, RJAS-08-17, MGA-12, KBGA-7, IC-032193, IC-035713 were found to be moderately tolerant with $26-50 \%$ leaf damage and was significantly lesser than in other genotypes (Table 2).

The genotypes IC-03711, BGA-2 and KBGA10 were found to be highly susceptible to leaf webber with 76-100 per cent leaf damage (Table 3).

Much effort has not been made on screening of genotypes against insect pests of grain amaranth. Thirty two genotypes were screened against leaf webber. At seedling stage 25 genotypes were found to be highly tolerant and 7 genotypes were found tolerant to leaf webber, respectively.

At vegetative stage, 16, 10 and 6 genotypes were found to be highly tolerant, tolerant and moderately tolerant against leaf webber, respectively. At grain filling stage 14, 15 and 3 genotypes were found to be moderately tolerant, susceptible and highly susceptible to leaf webber respectively. Amaranth genotypes viz.KBGA-5, RHGA-13-1, RHGA-13-2, RMA7, MGA-15, KBGA-4, BGA-38, BGA-43, SKGPA-75, RJAS-08-17, MGA-12, KBGA-7, IC-032193 and IC-035713 were tolerant at seedling, vegetative and grain filling stage and leaf damage was 0 to 50 per cent.

Resistant and tolerant cultivars form the basic component of Integrated Pest Management (IPM). Even a low level of tolerance in plants has a dramatic effect, which in fact reduces the need of insecticides. Use of resistant or lesssusceptible cultivars is one of the most important methods of keeping insect populations below economic threshold levels.

However, host-plant resistance is not a panacea for all pest problems. It is most useful when carefully utilized with other components of pest management. Pest resistant varieties, thus combating biotic stresses and reaping good yield is the need of the hour (Kavitha and Dharma Reddy, 2012).

Pest management involves several divergent measures to minimize the losses due to insect 
pests. Insect resistant varieties form an important component of pest management schedule. Thus resistance is a relative property and can be defined only in comparison to other more susceptible varieties (Sundarbabu, 1968).

\section{Acknowledgement}

Authors would like to thank Dr. C. A. Viraktamath, Principal investigator, Network Project on Biosystematics, Department of Entomology, Gandhi KrishiVignana Kendra (GKVK), Bengaluru and Dr. Niranjanamurthy, Breeder AICRP on Potential crops, GKVK, Bangalore for identifying the insect specimens.

\section{References}

Aderolu. I. A. I., Omooloye A. A. and Okelana F. A., 2013. Occurrence, abundance and control of the major insect pests associated with amaranths in Ibadan, Nigeria. Entomol.Ornithol.Herpetol.2: 59.

Agarwal, B. D., 1985. Biology of Hypolixus truncatulus (F). (Coleoptera: Curculionidae) forming galls on the stem of Amaranthus spinosus Lim. in India. Cecidologia Int., 6 (1-3): 83 -90.

Akinolosotu, T. A., 1977. A checklist of insects associated with local vegetables in South west Nigeria. Res. Bulletin, IAR and T. Ife. $5: 18-23$.

Batra, H. A. and Bhattacherjee, N. S., 1960. Occurrence of Hymenia recurvalis (Fabricius) (Lepidoptera: Pyalidae) as a bad pest on some leaf vegetables. Indian J. Entomol.22: 128-130.

Bhattacherjee, N. S. and Menon, R. M. G., 1964. Bionomics, biology and control of Hymenia recurvalis (Fabricius) (Lepidoptera: Pyralidae). Indian J.
Entomol.26 (2): 176-183.

Clarke-Harris, D. and Fleischer S. J., 2003. Sequential sampling and biorational chemistries for management of lepidopteran pests of vegetable amaranth in the Caribbean. J. Econ. Entomol. 96: 798-804.

Grovida, F., 2015.Vegetable pests. http://www.grovida.us/vegetablepests.ht $\mathrm{ml}$. Accessed on 26/5/2015.

James, B., Ahowe, A. C., Godonou, I., Baimey, H. and Georgen, H., 2010. Integrated pest management in vegetable production: A guide for extension workers in West Africa. International Institute of Tropical Agriculture (IITA), Ibadan, Nigeria.pp. 120.

Kavitha, K. and Dharma Reddy. K. 2012. Screening Techniques for Different insect Pests in Crop Plants. Int. J. Bioresource and Stress Management. 3(2): 188-195.

Okunlola, A. I., Ofuya, T. I. and Aladesanwa, R. D., 2008. Efficacy of plant extracts on major insect pests of selected leaf vegetables in South Western Nigeria. Agric. J. 3:181-184.

Picker, M., Griffiths, C. and Weaving, A., 2004. Field guide to insects of South Africa. South Africa: Struik Publishers.

Richard, R.W., 1989, Studies of insects feeding on grain Amaranth in the Mid-West. J. Kansas Entomol. Soc.62(4): 440-448.

Sorensen K. A., 1995. Insect pest of Vegetables. North Carolina Agricultural Extension Service. pp. 404.

Sundarababu, P. C., 1968.Studies on efficacy of thuricide in control of leaf webber/ caterpillar (Hymenia recurvalis) on amaranthus. Indian Horticulture. 16: 1719.

\section{How to cite this article:}

Anil, Prabhu Ganiger, Srinivas reddy and Niranjanamurthy. 2020. Evaluation Elite Grain Amaranth Genotypes for Major Insect-Pestresistance. Int.J.Curr.Microbiol.App.Sci. 9(08): 1465-1469. doi: https://doi.org/10.20546/ijcmas.2020.908.168 